\title{
Agrococcus citreus sp. nov., isolated from a medieval wall painting of the chapel of Castle Herberstein (Austria)
}

\author{
Monika Wieser, ${ }^{1,2}$ Peter Schumann, ${ }^{3}$ Karin Martin, ${ }^{4}$ Petra Altenburger, ${ }^{1,2}$ \\ Jutta Burghardt, ${ }^{5}$ Werner Lubitz ${ }^{1}$ and Hans-Jürgen Busse ${ }^{1,2}$
}

Author for correspondence: Hans-Jürgen Busse. Tel: +43125077 2119. Fax: +431250772190.
e-mail: Hans-Juergen.Busse@vu-wien.ac.at

\footnotetext{
1 Institut für Mikrobiologie und Genetik, Universität Wien, A-1030 Wien, Austria

2 Institut für Bakteriologie, Mykologie und Hygiene, Veterinärmedizinische Universität, A-1210 Wien, Austria

3 DSMZ-Deutsche Sammlung von Mikroorganismen und Zellkulturen $\mathrm{GmbH}$, Aussenstelle Jena, Germany

4 Hans-Knöll-Institut für Naturstoff-Forschung e. V., D-07745 Jena, Germany

5 DSMZ-Deutsche Sammlung von Mikroorganismen und Zellkulturen $\mathrm{GmbH}$, D-38124 Braunschweig, Germany
}

\begin{abstract}
A bacterial strain, D-1/1a', isolated from a medieval wall painting of the chapel of Herberstein (Styria, Austria) was characterized by a polyphasic approach. Strain D-1/1a' shared 98.1\% 165 rRNA sequence similarity to Agrococcus jenensis. The chemotaxonomic characteristics including polar lipid pattern, whole cell sugars, quinone system, polyamine pattern, cell wall composition and fatty acid profile were in good agreement with those of Agrococcus jenensis. The $\mathrm{G}+\mathrm{C}$ content of the DNA was determined to be $74 \mathrm{~mol} \%$. The value of $47 \%$ DNA reassociation obtained after DNA-DNA hybridization between DNA of Agrococcus jenensis and strain $\mathrm{D}-1 / 1 \mathrm{a}^{\top}$ as well as differences in the amino acid composition of the peptidoglycan and in physiological characteristics demonstrate that the isolate represents a new species of the genus Agrococcus. The name Agrococcus citreus sp. nov. is proposed for the new species harbouring isolate D-1/1a'. The type strain is DSM $12453^{\top}$.
\end{abstract}

Keywords: Agrococcus citreus sp. nov., 16S rDNA sequence analysis, chemotaxonomy, physiology, DNA reassociation

\section{INTRODUCTION}

Many unheated buildings of historic and artistic value with mural paintings, such as old churches, provide favourable conditions for the growth of certain microorganisms (Karpovich-Tate \& Rebrikova, 1990). Members of the actinomycetes are known to inhabit wall paintings of such places (Karpovich-Tate \& Rebrikova, 1990; Sorlini et al., 1987; Weirich, 1988;Petushkova et al., 1990; Altenburger et al., 1996).

During the course of isolation and classification of heterotrophic bacteria assumed to be responsible for biodecay from wall paintings in the chapel of the castle of Herberstein, a yellow pigmented coryneform bacterium was isolated. Here we describe the characterization of this strain, which could be clearly allocated to the genus Agrococcus. The name Agro-

Abbreviation: DAB, diaminobutyric acid

The EMBL accession number for the 165 rDNA sequence of strain $D-1 / 1 a^{\top}$ is AJ012826. coccus citreus sp. nov. is proposed. The type strain has been deposited in the German Collection of Microorganisms and Cell Cultures as strain DSM $12453^{\mathrm{T}}$.

\section{METHODS}

Bacterial strains and cultural conditions. Strain $\mathrm{D}-1 / 1 \mathrm{a}^{\mathrm{T}}$ was isolated from the medieval wall painting of the chapel of the castle Herberstein. Surface material was scraped off to a depth of 3-10 $\mathrm{mm}$ from areas showing extensive damage. Samples were collected in a sterile tube, suspended in sterile saline, shaken for $1 \mathrm{~h}$ and dilutions were transferred on PYES-agar plates $\left[3 \mathrm{~g}\right.$ peptone (from casein) $\mathrm{l}^{-1}, 3 \mathrm{~g}$ yeast extract $\mathrm{l}^{-1}, 2 \cdot 3 \mathrm{~g} \mathrm{Na}_{2}$-succinate $\mathrm{l}^{-1}$ (all from Merck), $\mathrm{pH} 7 \cdot 2$ ]. Incubation was performed at room temperature.

Morphological and physiological characteristics. Cell morphology was determined by using phase-contrast microscopy of cultures of different ages. Colony morphology was studied with a stereo microscope. Acid production from carbohydrates was tested using the method of Hugh \& Leifson (1953) modified by Gledhill \& Casida (1969). Utilization of organic acids was studied in the medium described by Cowan \& Steel (1965) by adding the sodium salts of organic acids to a final concentration of $0.2 \%$. 


\section{Table 1. Physiological properties of Agrococcus citreus and Agrococcus jenensis}

All three strains were negative for decomposition of adenine, gelatin, hippurate, hypoxanthine, Tween 80 , urea and xanthine, and acid production from cellobiose, dextrin, galactose, glucose, inulin, lactose, maltose, raffinose, salicin, sucrose, potato starch and trehalose, and utilization of benzoate, citrate, formate and DL-tartrate, and nitrate reduction. All three strains were negative in the Voges-Proskauer, methyl red, oxidase and indole tests. All three strains were positive for decompostion of aesculin, potato starch and tyrosine, and acid production from L-arabinose, fructose, mannitol, L-rhamnose, ribose and D-sorbitol, and utilization of acetate, and production of $\mathrm{H}_{2} \mathrm{~S}$ and catalase. All three strains were weakly positive for acid production from glycerol, mannose and D-xylose. All three strains grew in the presence of 2 or $4 \%$, but not $10 \%, \mathrm{NaCl}$. All three strains grew at 28 or $37^{\circ} \mathrm{C}$, but not at $50^{\circ} \mathrm{C}$. All three strains were susceptible to the following antibacterial agents: ampicillin, $10 \mu \mathrm{g}$; chloramphenicol, $30 \mu \mathrm{g}$; erythromycin, $15 \mu \mathrm{g}$; gentamicin, $10 \mu \mathrm{g}$; kanamycin, $30 \mu \mathrm{g}$; lincomycin, $2 \mu \mathrm{g}$; neomycin, $30 \mu \mathrm{g}$; oxacillin, $5 \mu \mathrm{g}$; tetracycline, $30 \mu \mathrm{g}$; penicillin G, $10 \mathrm{IU}$; rifampicin, $30 \mu \mathrm{g}$; and streptomycin, $10 \mu \mathrm{g}$. All three strains were weakly positive for susceptibility to $300 \mathrm{IU}$ polymyxin B and $200 \mu \mathrm{g}$ sulfonamide. W, Weakly positive.

\begin{tabular}{|c|c|c|c|}
\hline Character & $\begin{array}{l}\text { A. citreus } \\
\mathrm{D}-1 / \mathbf{1 a}^{\mathrm{T}}\end{array}$ & $\begin{array}{c}\text { A. jenensis } \\
\text { DSM } 9580^{\mathrm{T}}\end{array}$ & $\begin{array}{l}\text { A. jenensis } \\
\text { DSM } 9996\end{array}$ \\
\hline \multicolumn{4}{|l|}{ Decomposition of: } \\
\hline Casein & - & + & - \\
\hline \multicolumn{4}{|l|}{ Utilization of: } \\
\hline Aconitate & + & - & - \\
\hline Malate & - & + & + \\
\hline Succinate & - & + & + \\
\hline \multicolumn{4}{|l|}{ Antibiotic susceptibility: } \\
\hline Ciprofloxacin, $5 \mu \mathrm{g}$ & w & w & + \\
\hline Nitrofurantoin, $200 \mu \mathrm{g}$ & - & + & + \\
\hline
\end{tabular}

Nitrate reduction, urease activity, indole production, hydrogen sulfide production, hydrolysis of Tween 80 and gelatin, methyl red and Voges-Proskauer reactions were tested as described by Lanyi (1987). Catalase production and hydrolysis of casein and starch were tested by the methods of Gledhill \& Casida (1969). Decomposition of adenine, hypoxanthine, xanthine and tyrosine was determined as recommended by Gordon et al. (1974). Oxidase activity was tested by the oxidation of $1 \%$ tetramethyl- $p$ phenylenediamine solution on discs of filter paper (Cowan \& Steel, 1965). Hydrolysis of hippurate was carried out on hippurate agar (Cowan \& Steel, 1965). Growth was tested at 28 and $37^{\circ} \mathrm{C}, \mathrm{NaCl}$ tolerance was checked at concentrations between 2 and $10 \%$ on R-medium. Susceptibility to antibiotics was examined by placing antibiotic discs (bioMérieux) on R-medium agar plates (Yamada \& Komagata, 1972) seeded with a suspension of the test strains. Oxygen requirement was tested with Generbag anaer- and microaer-incubation systems (bioMérieux).

16S rDNA sequence analysis. The $16 \mathrm{~S}$ rRNA gene from strain $\mathrm{D}-1 / 1 \mathrm{a}^{\mathrm{T}}$ was amplified by the polymerase chain reaction (PCR) using the universal primers $27 \mathrm{f}$ and $1492 \mathrm{r}$ (Lane, 1991). Amplification products were purified as described by Muyzer et al. (1995) or by precipitation with PEG. For PEG precipitation, equal volumes of $\mathrm{PCR}$ products and $3 \mathrm{M} \mathrm{NaCl}$ solution containing $24 \%$ PEG 6000 were mixed, incubated at $37^{\circ} \mathrm{C}$ for $10 \mathrm{~min}$ and recovered by centrifugation at 16500 r.p.m. for $1 \mathrm{~h}$ at $4^{\circ} \mathrm{C}$. Purified PCR products were directly sequenced at the Service Department at the Vienna Biocentre (MIG-BASE) on a LI-COR 4000 L, as outlined by
Middendorf et al. (1992). The following fluorescently labelled primers were used: 27f, 926f, 530f and 1100r (Lane, 1991). The derived sequence was aligned and compared with those of other bacterial 16S rDNA sequences available in the EMBL database using the GCG program (Wisconsin Package, 1995).

DNA isolation and characterization. Isolation of DNA from acetone prewashed biomass and DNA-DNA hybridization (De Ley et al., 1970; Escara \& Hutton, 1980), as well as determination of renaturation rates (Huß et al., 1983; Jahnke, 1992), were performed as described previously. The $\mathrm{G}+\mathrm{C}$ content was determined as described previously (Groth et al., 1996).

Chemotaxonomic investigations. Menaquinones were extracted and analysed as described previously (Tindall, 1990). Polar lipids were extracted and analysed by TLC according to the methods of Ventosa et al. (1993). Cellular fatty acid methylesters were analysed according to Groth $e t$ al. (1996). Detection of the diagnostic cell-wall diamino acid was performed by the method of Schleifer (1985). Analysis of the cell-wall amino acids was done as described by Groth et al. (1997). Whole-cell sugars were determined by the method of Schaal (1985). Extraction and detection of polyamine pattern were performed as described by Altenburger et al. (1997). The HPLC system (Waters) was equipped with two model 510 HPLC pumps, an U6K injector, a reversed phase column (Hypersil ODS RP 18, $250 \times 4.6 \mathrm{~cm}, 5 \mu \mathrm{m}$ particles) and with a Jasco model $821-\mathrm{FP}$ fluorescence detector. 


\section{RESULTS}

\section{Morphological and cultural characteristics}

Colonies of the isolate $\mathrm{D}-1 / 1 \mathrm{a}^{\mathrm{T}}$ are yellow, opaque and convex with glistening surfaces in a range of $2-4 \mathrm{~mm}$ in diameter, colony margins are entire on nutrient agar. Cells of the isolate D-1/1 $\mathrm{a}^{\mathrm{T}}$ are Grampositive and have irregular coccoid to rod-shaped forms of $0.7-1.0 \times 1 \cdot 1-1.7 \mu \mathrm{m}$. Cells occur singly, in pairs or occasionally in irregular clusters. A mycelial growth phase was never observed. Strain D-1/1a grew well on complex organic media at $28^{\circ} \mathrm{C}$. At $37^{\circ} \mathrm{C}$ growth was observed, but not at $50^{\circ} \mathrm{C}$. No growth occurred under anaerobic conditions or in the presence of $10 \% \mathrm{NaCl}$.

\section{Physiological characteristics}

The physiological properties of the isolate $\mathrm{D}-1 / 1 \mathrm{a}^{\mathrm{T}}$ and those of the two Agrococcus jenensis strains DSM $9580^{\mathrm{T}}$ and DSM 9996 are summarized in Table 1 . In the recent study, the results of acid production from some sugars and of utilization of some organic compounds were found to be different from results reported previously for the type strain of the species Agrococcus jenensis (Groth et al., 1996). In contrast to the previous study, Agrococcus jenensis DSM $9580^{\mathrm{T}}$ produced acid from ribose, mannose and xylose but not from inulin, acetate was utilized and tyrosin decomposed. So far, this observation cannot be explained. Thus, these features should be considered as variable in the species description.

\section{Chemotaxonomic characteristics}

The major menaquinones detected in strain $\mathrm{D}-1 / 1 \mathrm{a}^{\mathrm{T}}$ were MK-11 and MK-12. The characteristic cell wall diamino acid was diaminobutyric acid (DAB). In addition, alanine, glycine, aspartic and glutamic acid were detected. The cell wall Ala-Gly-DAB-Asp-Glu ratio was $3 \cdot 6: 2 \cdot 1: 0 \cdot 8: 0 \cdot 9: 1 \cdot 0$. L-Asp was found to be the amino-terminal amino acid of the interpeptide bridge. Predominant fatty acids were ai- $\mathrm{C}_{15: 0}$, ai- $\mathrm{C}_{17: 0}$ and $\mathrm{i}-\mathrm{C}_{16: 0}$, whilst $\mathrm{i}-\mathrm{C}_{15: 0}, \mathrm{i}-\mathrm{C}_{15: 1}, \mathrm{i}-\mathrm{C}_{17: 0}$ and $\mathrm{C}_{16: 0}$ were present in minor amounts (Table 2). The poly-

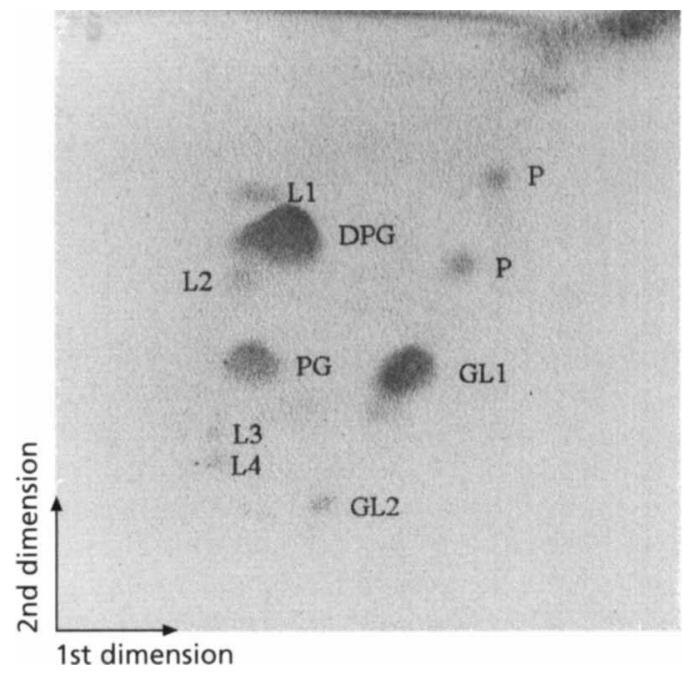

Fig. 1. Two-dimensional TLC of a polar lipid extract obtained from strain $D-1 / 1 a^{\top}$ and stained with molybdatophosphoric acid. DPG, diphosphatidylglycerol; PG, phosphatidylglycerol; GL1 and GL2, unknown glycolipids; L1-4, unknown polar lipids; $P$, pigments.

amine pattern contained mainly spermine. Diphosphatidylglycerol and phosphatidylglycerol were found to be predominant in the polar lipid extracts of the isolate D-1 $1 \mathrm{a}^{\mathrm{T}}$. In addition, two unknown glycolipids and four non-characterized lipids were detected (Fig. 1). The same polar lipid profile was detected in Agrococcus jenensis DSM $9580^{\mathrm{T}}$ (results not shown). The wholecell hydrolysate contained glucose, rhamnose, mannose, ribose, galactose and tyvelose.

\section{$16 S$ rDNA sequencing}

The analyses of the 16S rRNA coding gene of strain D$1 / 1 \mathrm{a}^{\mathrm{T}}$ resulted in a fragment of 1212 bases (positions 158-1392, Escherichia coli numbering; Brosius et al., 1978). Sequence comparison with homologous sequences showed that strain $\mathrm{D}-1 / 1 \mathrm{a}^{\mathrm{T}}$ shared the highest similarity with Agrococcus jenensis $(98 \cdot 1 \%)$. The sequence similarities to other species of the family Microbacteriaceae were in the range of $89.9 \%$ (Rathayibacter rathayi) and $93.8 \%$ (Aureobacterium testaceum and Microbacterium aurum).

Table 2. Fatty acid composition of Agrococcus jenensis DSM $9580^{\top}$ and strain D-1/1 $a^{\top}$

The abbreviations for fatty acids are illustrated by the following examples: $\mathrm{C}_{16: 0}$, hexadecanoic acid; $\mathrm{C}_{18: 1}$, octadecenoic acid; $\mathrm{i}-\mathrm{C}_{15: 0}, 13-$ methyltetradecanoic acid; ai- $\mathrm{C}_{15: 0}, 12-$ methyltetradecanoic acid.

\begin{tabular}{|c|c|c|c|c|c|c|c|c|c|c|c|c|c|c|}
\hline & $i-C_{14: 0}$ & $\mathrm{C}_{14: 0}$ & $i-C_{15: 0}$ & $\mathrm{i}-\mathrm{C}_{15: 1}$ & ai- $C_{15: 0}$ & $C_{15: 0}$ & $i-C_{16: 0}$ & $C_{16: 0}$ & $C_{16: 1}$ & $\mathrm{i}-\mathbf{C}_{17: 0}$ & $C_{17: 1}$ & ai- $C_{17: 0}$ & $C_{18: 0}$ & $C_{18: 1}$ \\
\hline $\begin{array}{l}\text { A. jenensis } \\
\text { DSM } 9580^{\mathrm{T}}\end{array}$ & $0 \cdot 6$ & $0 \cdot 3$ & $12 \cdot 2$ & 1.9 & $57 \cdot 8$ & & $12 \cdot 6$ & $2 \cdot 0$ & & 1.9 & & $9 \cdot 3$ & $0 \cdot 1$ & $0 \cdot 1$ \\
\hline$D-1 / 1 a^{T}$ & $0 \cdot 6$ & $0 \cdot 3$ & $10 \cdot 0$ & $5 \cdot 6$ & $53 \cdot 1$ & $0 \cdot 1$ & $12 \cdot 0$ & $1 \cdot 7$ & $0 \cdot 2$ & $1 \cdot 7$ & $0 \cdot 1$ & $13 \cdot 2$ & $0 \cdot 2$ & $0 \cdot 1$ \\
\hline
\end{tabular}




\section{$\mathbf{G}+\mathbf{C}$ content and DNA-DNA hybridization}

The $\mathrm{G}+\mathrm{C}$ content of the isolate $\mathrm{D}-1 / 1 \mathrm{a}^{\mathrm{T}} \mathrm{DNA}$ was determined to be $74 \mathrm{~mol} \%$. Strain D-1/1 $\mathrm{a}^{\mathrm{T}}$ exhibited a DNA reassociation value of $47 \%$ with Agrococcus jenensis DSM $9580^{\mathrm{T}}$.

\section{DISCUSSION}

Group B murein-containing bacteria are located in a separate branch within the class Actinobacteria and belong to the family Microbacteriaceae (Park et al., 1993; Rainey et al., 1994; Stackebrandt et al., 1997). The presence of diaminobutyric acid as diagnostic cell wall diamino acid is quite rare and only found in some taxa comprising the genera Clavibacter, Rathayibacter, Cryobacterium, Agromyces, Agrococcus, Leucobacter and in the misnamed species 'Brevibacterium helvolum' and 'Corynebacterium aquaticum' (Collins \& Jones, 1980; Davis et al., 1984; Döpfer et al., 1982; Groth et al., 1996; Sasaki et al., 1998; Suzuki et al., 1997; Takeuchi et al., 1996; Zgurskaya et al., 1992, 1993).

The partial analysis of the 16S rRNA sequence of strain $\mathrm{D}-1 / 1 \mathrm{a}^{\mathrm{T}}$ and comparison to other sequences indicated that this isolate belongs to the genus Agrococcus. The only species, Agrococcus jenensis is phylogenetically clearly separated from other members of the family Microbacteriaceae (Groth et al., 1996; Suzuki et al., 1997). Chemotaxonomic characteristics such as cell wall composition, polyamine pattern, menaquinone, whole cell sugars and fatty acid profile were in accordance with the characteristics of Agrococcus jenensis DSM $9580^{\mathrm{T}}$ and different from the other DAB-containing taxa (Groth et al., 1996; Altenburger et al., 1997). The polar lipid profile of strain D-1/1a $\mathrm{a}^{\mathrm{T}}$ was different from that reported for Agrococcus jenensis DSM $9580^{\mathrm{T}}$ (Groth et al., 1996). It consisted not only of phosphatidylglycerol, diphosphatidylglycerol and two unknown glycolipids, but also contained four non-characterized polar lipids. Reinvestigation of the polar lipid profile of Agrococcus jenensis DSM $9580^{\mathrm{T}}$ displayed the same constituents as found in strain D-1/1 $\mathrm{a}^{\mathrm{T}}$ (results not shown).

In respect to physiological properties, strain D-1/1 $\mathrm{a}^{\mathrm{T}}$ could be distinguished from the two strains of Agrococcus jenensis based on the utilization of three organic acids and susceptibility to an antibiotic. In contrast to Agrococcus jenensis strains, isolate D-1/1a ${ }^{\mathrm{T}}$ utilized aconitate, but not malate and succinate and it was resistant to nitrofurantoin.

DNA-DNA hybridization studies and cell wall analysis clearly indicate that strain D-1/1 $\mathrm{a}^{\mathrm{T}}$ and Agrococcus jenensis do not belong to the same species. Strain D$1 / 1 \mathrm{a}^{\mathrm{T}}$ exhibited a low level of DNA reassociation with Agrococcus jenensis $(47 \%)$. Furthermore the cell wall of isolate $\mathrm{D}-1 / 1 \mathrm{a}^{\mathrm{T}}$ contained no threonine and is therefore clearly distinguishable from that of Agrococcus jenensis.

On the basis of our results it is demonstrated that strain $\mathrm{D}-1 / 1 \mathrm{a}^{\mathrm{T}}$ represents a new species of the genus Agrococcus and we propose the name Agrococcus citreus sp. nov. for this strain.

\section{Description of Agrococcus citreus sp. nov.}

Agrococcus citreus (cit.re.us. M.L. adj. citreus describing the lemon-yellow pigmentation).

Cells are irregular spherical, ovoid or rodshaped. The cell sizes vary in a range of $0.7-1 \cdot 0 \times 1 \cdot 1-1 \cdot 7 \mu \mathrm{m}$. Cells occur singly, in pairs or in small irregular clusters. They are Gram-positive and non-motile. Endospores are not formed, colonies are slight convex and smooth. Colony diameters are in a range of $2-4 \mathrm{~mm}$. The colour of the colonies on nutrient agar is yellow. Aerobic and microaerophilic. Catalase is produced. Oxidase-negative. Nitrate is not reduced to nitrite. Acids are produced from arabinose, fructose, mannitol, rhamnose, ribose and sorbitol. A weak acid production is observed from mannose, glycerol and xylose. No acid production was observed from cellobiose, dextrin, galactose, glucose, glycerol, inulin, lactose, maltose, raffinose, salicin, sucrose, starch or trehalose. Acetate and aconitate are utilized as carbon sources. Benzoate, citrate, formate, malate, succinate and tartrate are not utilized. Starch, aesculin and tyrosine are decomposed. Adenine, casein, gelatin, hippurate, xanthine, hypoxanthine, urea and tween 80 are not decomposed. Cells are susceptible to ampicillin, chloramphenicol, ciprofloxacin, erythromycin, gentamicin, kanamycin, lincomycin, neomycin, oxacillin, tetracycline, penicillin $\mathrm{G}$, polymyxin $\mathrm{B}$, rifampicin and streptomycin. Isolate $\mathrm{D}-1 / 1 \mathrm{a}^{\mathrm{T}}$ is resistant to nitrofurantoin. The cell wall diamino acid is diaminobutyric acid (DAB), additionally alanine, glycine, glutamic acid, and aspartic acid are found. No threonine is present. The whole cell sugars are glucose, rhamnose, mannose, ribose, galactose and tyvelose. The polar lipid profile is composed of diphosphatidylglycerol, phosphatidylglycerol, two unknown glycolipids and four uncharacterized polar lipids. The fatty acid profile consists of the predominant compounds ai- $\mathrm{C}_{15: 0}$, ai- $\mathrm{C}_{17: 0}$ and $\mathrm{i}-\mathrm{C}_{16: 0}$, whereas $\mathrm{i}-\mathrm{C}_{15: 0}, \mathrm{i}-\mathrm{C}_{15: 1}, \mathrm{i}-\mathrm{C}_{17: 0}$ and $\mathrm{C}_{16: 0}$ were present in minor amounts. The main menaquinones are MK-11 and MK-12. Spermine is the predominant compound in the polyamine pattern. The $\mathrm{G}+\mathrm{C}$ content is $74 \mathrm{~mol} \%$. Strain $\mathrm{D}-1 / 1 \mathrm{a}^{\mathrm{T}}$ has been isolated from a medieval wall painting in the church of castle Herberstein in Styria, Austria. The type strain, $\mathrm{D}-1 / 1 \mathrm{a}^{\mathrm{T}}$, has been deposited in the DSMZ-German Collection of Microorganisms and Cell Cultures, Braunschweig, Germany, as strain DSM $12453^{\mathrm{T}}$.

\section{REFERENCES}

Altenburger, P., Kämpfer, P., Makristathis, A., Lubitz, W. \& Busse, H.-J. (1996). Classification of bacteria isolated from a medieval wall painting. $J$ Biotechnol 47, 39-52.

Altenburger, P., Kämpfer, P., Akimov, V. N. , Lubitz, W. \& Busse, H.-J. (1997). Polyamine distribution in actinomycetes with group 
B peptidoglycan and species of the genera Brevibacterium, Corynebacterium, and Tsukamurella. Int J Syst Bacteriol 47, 270-277.

Brosius, J., Palmer, M. L., Kennedy, P. J. \& Noller, H. F. (1978). Complete nucleotide sequence of a $16 \mathrm{~S}$ ribosomal RNA gene from Escherichia coli. Proc Natl Acad Sci USA 75, 4801-4805.

Collins, M. D. \& Jones, D. (1980). Lipids in the classification and identification of coryneform bacteria containing peptidoglycans based on 2,4-diaminobutyric acid. J Appl Bacteriol 48, 459-470.

Cowan, S. T. \& Steel, K. J. (1965). Manual for the Identification of Medical Bacteria. Cambridge: Cambridge University Press.

Davis, M. J., Gillaspie, A. G., Vidaver, A. K. \& Harris, R. W. (1984). Clavibacter: a new genus containing some phytopathogenic coryneform bacteria, including Clavibacter xyli subsp. xyli sp. nov., subsp. nov. and Clavibacter xyli subsp. cynodontis subsp. nov., pathogens that cause ratoon stunting disease of sugarcane and Bermudagrass stunting disease. Int $J$ Syst Bacteriol 34, 107-117.

De Ley, J., Cattoir, H. \& Reynaerts (1970). The quantitative measurement of DNA hybridisation from renaturation rates. Eur J Biochem 12, 133-142.

Döpfer, H., Stackebrandt, E. \& Fiedler, F. (1982). Nucleic acid hybridization studies on Microbacterium, Curtobacterium, Agromyces and related taxa. J Gen Microbiol 128, 1697-1708.

Escara, J. F. \& Hutton, J. R. (1980). Thermal stability and renaturation of DNA in dimethylsulphoxide solution: acceleration of renaturation rate. Biopolymers 69, 33-80.

Gledhill, W. E. \& Casida, L. E., Jr (1969). Predominant catalasenegative soil bacteria. III. Agromyces, gen. n., microorganisms intermediary to Actinomyces and Nocardia. Appl Microbiol 18, 340-349.

Gordon, R. E., Barnett, D. A., Handerhan, J. E. \& Pang, C. H.-N. (1974). Nocardia coeliaca, Nocardia autotrophica, and the nocardin strain. Int J Syst Bacteriol 24, 54-63.

Groth, I., Schumann, P., Weiss, N., Martin, K. \& Rainey, F. A. (1996). Agrococcus jenensis gen. nov., sp. nov., a new genus of Actinomycetes with diaminobutyric acid in the cell wall. Int $J$ Syst Bacteriol 46, 234-239.

Groth, I., Schumann, P., Rainey, F. A., Martin, K., Schuetze, B. \& Augsten, K. (1997). Bogoriella caseilytica gen. nov., sp. nov., a new alkaliphilic actinomycete from a soda lake in Africa. Int $J$ Syst Bacteriol 47, 788-794.

Hugh, R. \& Leifson, E. (1953). The taxonomic significance of fermentative versus oxidative metabolism of carbohydrates by various Gram negative bacteria. J Bacteriol 66, 24.

Huß, V. A. R., Festl, H. \& Schleifer, K. H. (1983). Studies on the spectrophotometric determination of DNA hybridization from renaturation rates. Syst Appl Microbiol 4, 184-192.

Jahnke, K.-D. (1992). BASIC computer program for evaluation of spectroscopic DNA renaturation data from GILFORD SYSTEM 2600 spectrophotometer on a PC/XT/AT type personal computer. J Microbiol Methods 15, 61-73.

Karpovich-Tate, N. \& Rebrikova, N. L. (1990). Microbial communities on damaged frescoes and building materials in the cathedral of the nativity of the virgin in the Pafnutii-Borovskii Monastery, Russia. Int Biodeterior 27, 281-296.

Lane, D. J. (1991). 16S/23S rRNA sequencing. In Nucleic Acid Techniques in Bacterial Systematics, pp. 115-175. Edited by E. Stackebrandt \& M. Goodfellow. Chichester: Wiley.

Lanyi, B. (1987). Classical and rapid identification methods for medically important bacteria. Methods Microbiol 19, 1-67.
Middendorf, L. R., Bruce, J. C., Bruce, R. C. \& 8 other authors (1992). Continous, on-line DNA sequencing using a versatile infrared laser scanner/electrophoresis apparatus. Electrophoresis 13, 487-494.

Muyzer, G., Hottenträger, S., Teske, A. \& Wawer, C. (1995). Denaturating gradient gel electrophoresis of PCR-amplified 16S rDNA - a new molecular approach to analyse the genetic diversity of mixed microbial communities. In Molecular Microbial Ecology Manual, 2nd edn, pp. 3.4.4.1-3.4.4.22. Edited by A. D. L. Akkermans, J. D. van Elsas \& F. J. de Bruijn. Dordrecht, The Netherlands: Kluwer.

Park, Y. H., Suzuki, K., Yun, D. G. \& 7 other authors (1993). Suprageneric classification of peptidoglycan group B actinomycetes by nucleotide sequencing of $5 \mathrm{~S}$ ribosomal RNA. Antonie Leeuwenhoek 64, 307-313.

Petushkova, Yu. P., Lyalikova, N. N. \& Poglasova, M. N. (1990). Microorganisms discovered on the frescoes of the Ferapoint Monastery. Mikrobiologiya 58, 1021-1030 (in Russian).

Rainey, F., Weiss, N., Prauser, H. \& Stackebrandt, E. (1994). Further evidence for the phylogenetic coherence of Actinomycetes with group B-peptidoglycan and evidence for the phylogenetic intermixing of the genera Microbacterium and Aureobacterium as determined by $16 \mathrm{~S}$ rDNA analysis. FEMS Microbiol Lett 118, 135-140.

Sasaki, J., Chijimatsu, M. \& Suzuki, K. (1998). Taxonomic significance of 2,4-diaminobutyric acid isomers in the cell wall peptidoglycan of actinomycetes and reclassification of Clavibacter toxicus as Rathayibacter toxicus comb. nov. Int $J$ Syst Bacteriol 48, 403-410.

Schaal, K. P. (1985). Identification of clinical significant actinomycetes and related bacteria using chemical techniques. In Chemical Methods In Bacterial Systematics, pp. 359-381. Edited by M. Goodfellow \& D. E. Minnikin. London: Academic Press. Schleifer, K. H. (1985). Analysis of the chemical composition and primary structure of murein. Methods Microbiol 18, 123-156.

Sorlini, C., Sacchi, M. \& Ferrari, A. (1987). Microbiological deterioration of Gambara's frescoes exposed to open air in Brescia, Italy. Int Biodeterior 23, 167-179.

Suzuki, K.-I., Sasaki, J., Uramoto, M., Nakase, T. \& Komagata, K. (1997). Cryobacterium psychrophilum gen. nov., sp. nov., nom. rev., comb. nov., an obligately psychrophilic actinomycete to accomondate 'Curtobacterium psychrophilum' Inoue and Komagata 1976. Int J Syst Bacteriol 47, 474-478.

Stackebrandt, E., Rainey, F. A. \& Ward-Rainey, N. L. (1997). Proposal for a new hierarchic classification system, Actinobacteria classis nov. Int $J$ Syst Bacteriol 47, 479-491.

Takeuchi, M., Weiss, N., Schumann, P. \& Yokota, A. (1996). Leucobacter komagatae gen. nov., sp. nov., a new aerobic grampositive, nonsporulating rod with 2,4-diaminobutyric acid in the cell wall. Int J Syst Bacteriol 46, 967-971.

Tindall, B. J. (1990). Lipid composition of Halobacterium lacusprofundi. FEMS Microbiol Lett 66, 199-202.

Ventosa, A., Marquez, M. C., Kocur, M. \& Tindall, B. J. (1993). Comparative study of "Micrococcus sp." strains CCM 168 and CCM 1405 and members of the genus Salinicoccus. Int J Syst Bacteriol 43, 245-248.

Weirich, G. (1988). Wachstum von Schimmelpilzen und Bakterien auf verschiedenen Malgründen. $Z$ Kunsttechn Konserv 2, 305-314.

Wisconsin Package (1995). Version 8.1 Program Manual. Genetics Computer Group, 575 Science Drive, Madison, Wisconsin, USA. 
Yamada, K. \& Komagata, K. (1972). Taxonomic studies on coryneform bacteria, IV. Morphological, cultural, biochemical, and physiological characteristics. J Gen Appl Microbiol 18, 339-416.

Zgurskaya, H. I., Evtushenko, L. I., Akimov, V. N., Voyevoda, H. V., Dobrovolskaya, T. G., Lysak, L. V. \& Kalakoutskii, L. V. (1992). Emended description of the genus Agromyces and description of Agromyces cerinus subsp. cerinus sp. nov., subsp. nov.,
Agromyces cerinus subsp. nitratus sp. nov., subsp. nov., Agromyces fucosus subsp. fucosus subsp. hippuratus sp. nov. , subsp. nov. Int J Syst Bacteriol 42, 635-641.

Zgurskaya, H. I., Evtushenko, L. I., Akimov, V. N. \& Kalakoutskii, L. V. (1993). Rathayibacter gen. nov., including the species Rathayibacter rathayi comb. nov., Rathayibacter tritici comb. nov., Rathayibacter iranicus comb. nov., and six strains from annual grasses. Int $J$ Syst Bacteriol 43, 143-149. 